\title{
Technology Transferring Performance of Chinese Universities: Insights from Patent Licensing Data
}

\author{
Xiaopei Gao, Wei Song, Xiaobao Peng, Xiaoyan Song \\ School of Public Affairs, University of Science \& Technology of China, Hefei, China \\ Email: gxp0406@mail.ustc.edu.cn, songwei@ustc.edu.cn, pxb1982@ustc.edu.cn, sxy@ustc.edu.cn
}

Received 23 October 2014; revised 18 November 2014; accepted 29 November 2014

Copyright (C) 2014 by authors and Scientific Research Publishing Inc.

This work is licensed under the Creative Commons Attribution International License (CC BY).

http://creativecommons.org/licenses/by/4.0/

c) (i) Open Access

\section{Abstract}

This paper had collected the patent licensing documents of all Chinese universities and made a comprehensive study on licensing performance. With a whole set of data from SIPO, the exact licensing frequency number and licensing propensity number of Chinese universities had been obtained for the first time. On average, 16.03 patents $(6 \%)$ per university had been licensed out to the industry, which is much lower than expectations. The frequency of licensing, propensity of licensing, number of partners (licensees), number of patent stocks, local-transfer ratio and the distribution of licensing frequency in terms of university-firm distance had been obtained in details. Five hypotheses had been made to discover the variances in university licensing performance. With the ANOVA technique, five hypotheses had been confirmed within the dataset, which had revealed a significant effect of patent stocks, local economic performance, central government support, existence of TTO and local government administration on university licensing performance.

\section{Keywords}

Patent, Licensing, University-Industry, Technology Transfer, China

\section{Introduction}

The knowledge and technology transferring from public universities to the private sectors had obtained attentions in the academic research. Previous works had brought up the importance of this phenomenon (Abramo, D’Angelo, \& Solazzi, 2012; Lei et al., 2012; Mowery \& Ziedonis, 2002). And various channels of knowledge transferring had been recognized in previous studies (Agrawal, 2001; W. M. Cohen, Nelson, \& Walsh, 2002; Colyvas et al., 2002; Scott Shane, 2002), including publications, conferences, consulting, joint ventures, per- 
sonnel exchange, scientist migration to the private sectors and so on. Patent licensing is one of the crucial channels of university-industry knowledge transferring. The out-licensing behavior of universities had also been considered as a way to fulfill the Third Mission of public research institutions (Wang, Huang, Chen, Pan, \& Chen, 2013; Wu \& Zhou, 2012).

Previous works about universities patents licensing behavior had viewed licensing data as a crucial outcome to measure the innovation productivities and an indicator of knowledge diffusion and collaboration. These works had taken various perspectives in the research of patent licensing. Baldini had reviewed academic papers about universities patenting and licensing and summarized those papers into 2 categories, one investigating the patent performances and the other one focusing on factors that had influenced the performances of universities patenting and licensing (Baldini, 2006). The first category includes papers like Mowery’s (Mowery, Nelson, Sampat, \& Ziedonis, 2001; Mowery \& Ziedonis, 2002). They had investigated the change of patent quantity and quality before and after the Bayh-Dole Act. The licensing portfolio and data had been used as a measurement of patent quantity and quality. Lee had used the licensing behavior to evaluate the quality of a patent. Patents which had been licensed out to private firms were considered to be of more values (Lee, 2008). The second category had attracted a lot of academic attentions and works in this field are fruitful. Thursby etc.'s work had used the number of licensing agreement as one of the output of universities commercialization and traced the factors that had impact on licensing productivity (Thursby \& Kemp, 2002; Thursby, J. G. \& Thursby, M. C, 2002). Shane and Somaya had focused on the effects of litigation issues on the number of licensing activities of universities and find the effects to be mainly negative (S. Shane \& Somaya, 2007). Agrawal had made an excellent review on this category and brought up 4 kinds of factors that had impacts on patenting and licensing behaviors, including firm characteristics, universities characteristics, geography factors and the various channels of knowledge transfer (Agrawal, 2001).

However, licensing activities had only been considered as tools to measure certain constructs in those studies. They used limited licensing data to capture certain attributes for their study purpose. For example, the works by Mowery and Ziedonis were based on surveys of 3 US leading universities, which were not representative for the entire US universities (Mowery \& Ziedonis, 2002). Studies about Chinese university patenting and licensing had mainly focused on the patent application, citation and collaboration behaviors (Gao, Guo, \& Guan, 2014; Hong, 2008; Li-Ying, Wang, Salomo, \& Vanhaverbeke, 2013; Luan, Zhou, \& Liu, 2010) and had mainly used data from USPTO (US Patent and Trademark Office) or DII (Derwent Innovations Index) (Lei et al., 2012; Li-Ying et al., 2013) rather than from SIPO (the State Intellectual Property Office of the P.R.C), which had the relative complete set of patenting and licensing documents of Chinese entities. The whole picture of universities patents licensing, as a prevailing and important phenomenon, had not been studies in a comprehensive way. Although previous studies had got into deeper issues about university licensing behaviors, some simple but important questions remain unexplored. What portion of patents had been licensed out in universities? What portion did universities transfer patents to local companies in the practice? In which perspective do universities differ in licensing activities in the real world? To answer those questions, an overall basic study of licensing behavior among universities should be taken to obtain details in these basic issues.

This paper had gathered the patents licensing documents of all Chinese universities from 2002 to 2012 in the online database of SIPO (the State Intellectual Property Office of the P.R.C), analyzing the patterns of licensing behaviors of universities. The study had collected all the licensing documents about Chinese universities and the result could be interpreted as the overall performance of Chinese universities in patent licensing. This paper had taken a geographical perspective on the university licensing behaviors and obtained some interesting and crucial results.

The second section of this paper had made a general analysis on the performance of Chinese universities licensing activities. These exact data about Chinese university patent licensing activities had not been revealed in other works and it is the first time to know the actual performance of university licensing. The third section of this paper mainly focuses on the variance in the licensing performance. 5 hypotheses had been made and the analyses of variance technique (ANOVA) had been implemented to test those hypotheses. The fourth section is discussion and conclusions from the main results. The main contribution of this study is revealing the exact data on Chinese university licensing performance for the first time. The exact data on every university could generate more insight on this knowledge transferring process. 


\section{Data Source and Methods}

The licensing documents data of all the Chinese universities and colleges from 2002 to 2012 had been collected from the online database in SIPO (the State Intellectual Property Office of the P.R.C). In the year of 2002, a law had been enacted to enforce the patent licensing activities been recorded on the national patent system. Only those documents that had been listed in the system would be protected by the national law. In that case, licensing activities documented in the system were the actual legal patent licensing activities happened in the real world. The data obtained from SIPO online database included all the licensing activities that were conducted by universities. The documents had information about licensed patents, including the licensers, licensees, terms and territories. One document indicates one licensing activity. In the following study, the amount of registered document had been used as licensing frequency (LF for short). Most of these universities only act as licensor in the licensing activities, meaning that they only transfer technologies to other entities: as we defined as out-licensing. A few of them had been acted as both licensers and licensees, meaning that there were technologies transferring through universities and other entities in both ways: in-licensing and out-licensing. In the data that had been collected, there are 5688 out-licensing documents and 39 in-licensing documents in Chinese universities. In-licensing took a very small part in technology transferring and this paper will not explore this kind of licensing behavior. The paper mainly focuses on the out-licensing behaviors of the universities, which indicates the knowledge transferring from public-funded sectors to the private sectors. The LF in the following studies contains out-licensing frequencies only.

\section{Results}

354 universities had been identified in the dataset. By the end of 2012, there are 2498 universities and colleges in China, and 354 of them had been involved in licensing activities. Only $14.21 \%$ of these higher education institutions had transferred knowledge to industry through licensing channel, which was a rather low level of portion.

\subsection{Performance of Chinese University Licensing Activities}

In Table 1, the statistical results of these 4 variables indicated that the patent licensing behavior of Chinese universities is not active. The patent stock number, licensing frequency, licensing propensity and out degree of universities had been used to measure licensing activities. Patent stock number includes all the valid patents that were entitled to an organization from 1985 (the year that the Chinese Patent Law been passed) to 2012. Licensing frequency was defined as the frequency of licensing behavior. And in this study, the number of licensing frequency equals to the number of licensing documents. The average licensing frequency of these 354 universities is 16.03 , much fewer than the average patent stock number 520.89 . Licensing propensity is the licensing frequency number divided by the patents stock number, stands for the proportion of patents that had been licensed. And in this dataset, only $6 \%$ of patents on average had been licensed out to other organization, which was a very small portion. Out degree is a concept that is mainly used in social network studies. Out degrees could be interpreted as the number of organizations that have licensing relationships with a university. And the average out degree in this study equals to 12.10 .

To have a more vivid view on the university licensing frequency, a set of description diagrams had been shown on Figure 1. These 2 diagrams all reflected the distribution of LF in those 354 universities, but in different styles. What had been told on Figure 1 was that there is just little number of universities that had been involved in intensive licensing activities (shown as plots higher than the upper range in the box-plot diagram). The majority of actors had much lower level of LF (shown as the major area of the density diagram lies below 50).

\begin{tabular}{ccccc} 
Table 1. Basic statistical results. & & & \\
\hline & $\mathrm{n}$ & Mean & sd & Median \\
\hline Patent Stock & 354 & 520.89 & 901.41 & 215 \\
Licensing Frequency & 354 & 16.03 & 32.43 & 5 \\
Licensing Propensity & 354 & 0.06 & 0.14 & 0.03 \\
Out Degree & 354 & 12.10 & 24.10 & 4 \\
\hline
\end{tabular}



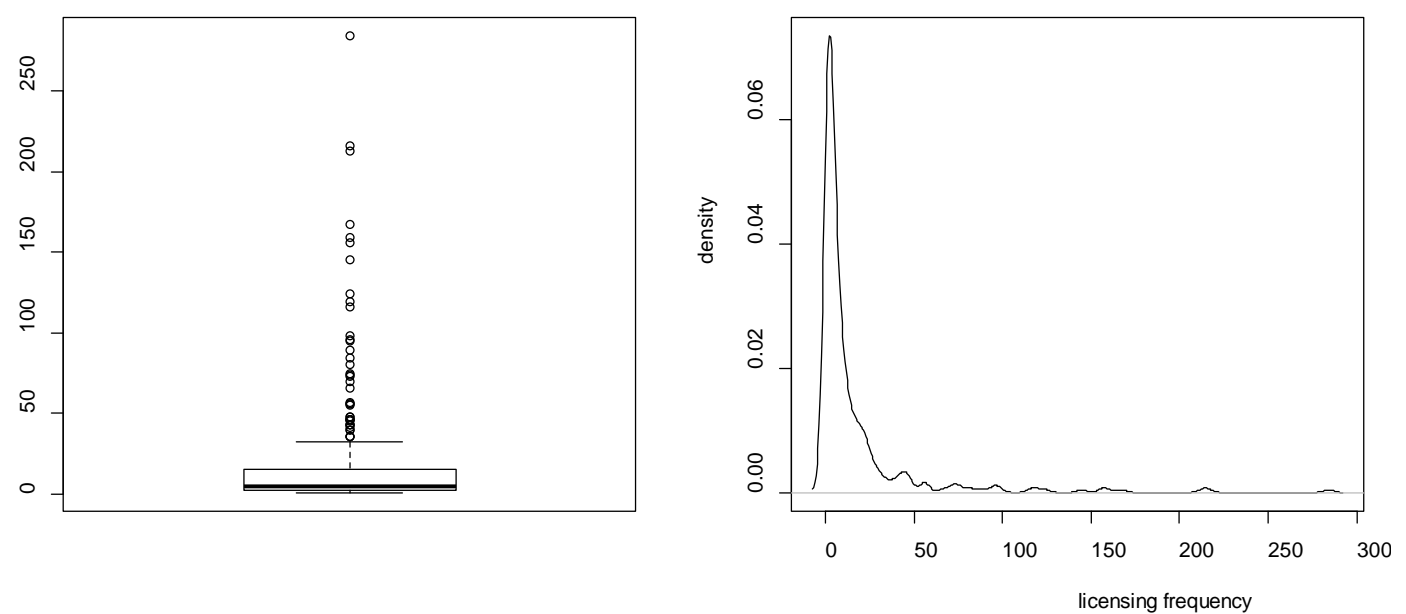

Figure 1. The distribution of licensing frequency.

These results correlate with the traditional perspectives on Chinese university licensing activities that a large portion (94\%) of patents from universities had not been transferred into economic productivity. The patent licensing of Chinese universities are highly skewed with a few number of universities act as main participants.

Besides how many patents had been licensed-out, the licensing direction also matters. Did the technologies developed in academy be transferred to companies near the universities, or did the enterprises in other areas gained the benefit? In China, most universities were financially supported by local government. A few of them also receive grants from departments and affiliations of the central government. Whether the local industry could take back their investment in the local universities is a critical issue for the native government.

The locations of each universities and licensee enterprises were collected. Replacing each entity in their location, a network of licensing directions had been made. Those patents that had been licensed out to companies in the same province had been considered as local transferring. Those patents that had been licensed out to companies whose address were not in the same province had been considered as non-local transferring.

Table 2 had shown the basic statistics about local licensing behavior. As had been stated in the early paragraph, the average licensing frequency about those 354 universities is 16.03. In Table 2, the mean of local licensing frequency is 9.64 and the mean of non-local licensing frequency is 7.53. The average licensing frequency of local transferring is a little more than non-local transferring. Local ratio had been used to identify the portion of local licensing behavior. The mean of local ratio equals to 0.60 , meaning that about $60 \%$ of patents licensing activities had been conducted between firms and universities in the same province. In the total 354 universities, 104 (less than one third) of them had only transferred patents to local companies, with their local ratio equal to 1.Considering the other 250 universities who had anticipated in non-local technology transferring, the average local ratio of them equals to 0.45 , meaning that about $45 \%$ of licensing behaviors were locally conducted. From the data in Table 2, the Chinese universities did have a propensity to transfer patents to the local firms.

The distance between universities and firms had been collected on the district level. The measurement of distance was the distance of high ways between city centers in the online service of Google maps. If the universities and firms were in the same city, the distance between them would be marked as $100 \mathrm{~km}$. We had collected the distance data about those 5688 licensing documents and the average distance between licensers and licensees was $575.76 \mathrm{~km}$, with a standard deviation of 698.24. About 2066 (41\%) of these licensing activities were conducted between universities and companies whose distances were within $100 \mathrm{~km}$. If focus on the other 3622 licensing activities, the average distance between universities and firms was $912.68 \mathrm{~km}$, with a standard deviation of 747.53. The basic statistical results only tell part of the story. To have a clear vision on the patterns of licensing distance, a histogram of distance distribution had been made.

The first picture in Figure 2 shows the distribution of distance in the whole 5688 licensing documents. The distance within $100 \mathrm{~km}$ took large portion in the diagram. With the increase of distance, the frequency dropped dramatically. To have a more clear vision on the patterns of distance frequency distribution above $100 \mathrm{~km}$, the 
Table 2. Statistics of licensing directions.

\begin{tabular}{cccc}
\hline & Mean & sd & Median \\
\hline Total & 16.03 & 32.43 & 5 \\
Local & 9.64 & 24.42 & 3 \\
Non-Local & 7.53 & 18.41 & 2 \\
Local Ratio & 0.60 & 0.36 & 0.67 \\
Local Ratio (Less than 1) & 0.45 & 0.31 & 0.5 \\
Distance (Total) & 575.76 & 698.24 & 170 \\
Distance (More than 100 km) & 912.68 & 747.53 & 735
\end{tabular}

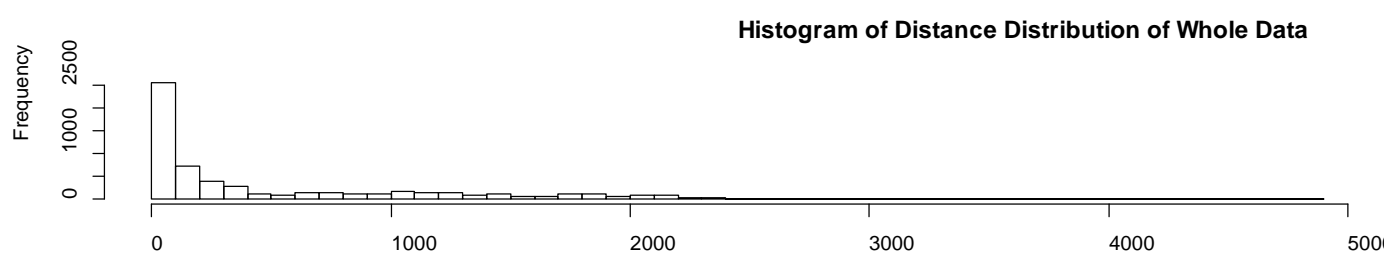

Histogram of Distance Distribution of Distance $>100$

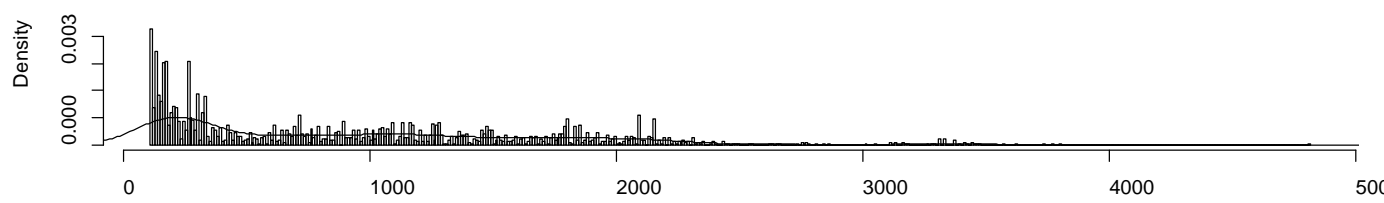

Figure 2. Distribution of university-company distance.

second picture in Figure 2 had cleared out the data in $100 \mathrm{~km}$. In the remaining 3622 data, the distribution of frequency mainly decreased with the increase of distance, which compile with the traditional thoughts. However, the obvious decreasing trend is not obvious when the distance had increased to about $400 \mathrm{~km}$. A solid line was used to measure the density of distance frequency distribution. From around $400 \mathrm{~km}$ to $2200 \mathrm{~km}$, the decreasing trend of density lines had stopped and the distribution of frequency had reached a relative stable period. Within this extent of distance, the frequency of licensing does not drop with the increase of distance. The frequency decreased dramatically again when the distance increased above $2200 \mathrm{~km}$.

These patterns in Figure 2 imply that a large portion of licensing activities were conducted between universities and firms whose distances were within $100 \mathrm{~km}$. The patterns of distribution when the distance is above 100 $\mathrm{km}$ implied that when the distance between universities and firms were relatively low (within $400 \mathrm{~km}$ ), the frequency of licensing activities dropped dramatically. When the distance between them were much higher (from $400 \mathrm{~km}$ to $2200 \mathrm{~km}$ ), distance did not show its impacts on the frequency of licensing. When the distance increased above $2200 \mathrm{~km}$, licensing frequency trend returned to a relative dramatic downside. The frequency of licensing activities does show a variant in the distance between licensors and licensees. However when the distance is not so near and not so far away, the impact of distance was limited.

\subsection{Variances in Licensing Performance}

The licensing frequency and licensing directions shows a diversified pattern on each university. While a very small amount of them actively engaged in licensing activities, the other more universities did not. The resource and characteristics of transfer agent (universities or public labs) is a very important factor that could affect the performance of technology transfer. A large number of previous works had focused on this issue (Agrawal, 2001; Bozeman, 2000). According to this kind of view, the patterns of licensing activities should display variety in universities with different characteristics and resources. To have a more clear view on the patterns of Chinese university licensing activities, the following hypothesis had been made: 
H1: Universities with more patent stocks show more engagement on licensing activities.

Patents stock number had been considered to be relevant to licensing activities. It is a very common knowledge that the more one have, the more one can use. With the same level of licensing propensity, universities with more patent stocks would have more patents to be licensed out. In the analyze process, valid patents applied from 1985 (the year that the Chinese Patent Law been passed) to the end of 2012 had been collected as universities patent stock numbers.

H2: Universities located in economically developed areas show more engagement on licensing activities.

The economic environment around universities was supposed to have influence on university-industry technology transfer. Previous results (in this paper) on university licensing directions revealed that a large portion of licensing activities were conducted between universities and firms in the same province. The local economic environment had impacts on technology recipients for that a prosperous local economy would attract more companies and increase the probability of invention exposure to the industry thus enhances licensing practice engagement. In the analyze process, the 2012 GDP of university native provinces and cities had been collected to measure the local economy development.

H3: Universities which gained central government support show more engagement on licensing activities.

As one of the element in "triple helix for innovation", government could show great impacts on this innovation system (Etzkowitz \& Leydesdorff, 2000). As in the context of Chinese public administration environment, the support from government, especially from central government department, would have impacts on the resources and funds that universities could have access to. It would be reasonable to expect that universities with support from central government could have more resources to initiate the commercialization of academic inventions. In the analyze process, the university's superior administration department had been collected to illustrate whether the support were from central government or local government.

H4: Universities which had official TTO (Technology Transfer Office) show more engagement on licensing activities.

The effects of Technology Transfer Office on university licensing activities had been studied for a long time. A formal organizational unit for technology transfer could provide specialized services for inventors and reduce the asymmetric information problem between academics and industry (Macho-Stadler, Perez-Castrillo, \& Veugelers, 2007). Universities with official TTOs in organization structure were supposed to be more efficient in innovation commercialization and show good performance in universities patent licensing. In the analyze process, the existence of official TTOs in university organizational structure had been collected.

H5: Universities which was supervised by local government show more engagement on local licensing activities.

Most universities in China were publicly funded and were supervised by departments in local government or central government. The Ministry of Education of the People's Republic of China is the most powerful department in central government in universities administration. It is reasonable to suppose that universities funded and supervised by local government would contribute more in the local economy, and patents licensed to local industry is one form of the contributions. In the analyze process, the university's superior administration department had been collected. Samples in universities with local government administrations were identical to the samples in universities without central government support, for these data were all based on the affiliation relations of universities with the government.

In order to test these 5 hypotheses, an independent one way analysis of variance (ANOVA) method had been used to capturing the differences in licensing activities performances varied on factors in 5 hypotheses. The dependent variables used to measure engagement in licensing activities included licensing frequency (LF), licensing propensity (LP), and out-degree (which represent the net number of licensees). The dependent variables used to measure the engagement on local licensing activities included the number of local licensing and the ratio of local licensing. The dependent variables, independent variables and variable categories implemented in ANOVA were presented on Table 3 and Table 4. Eight military universities had been put off from the dataset for their independence from society and the lack of basic information. Data about 352 universities had been implemented in ANOVA. Before running ANOVA, the homogeneity of group variance had to be tested. In this part of analysis, the Levene Test method had been used to test the homogeneity of group variance. The results were shown on Table 5.

Table 6 showed the main results in a serial of one way ANOVA, including the F-value, $P$-value and Eta squared value of these analyses. Those with $P$ value less than 0.01 were considered to have significant difference 
Table 3. The dependent variables in ANOVA.

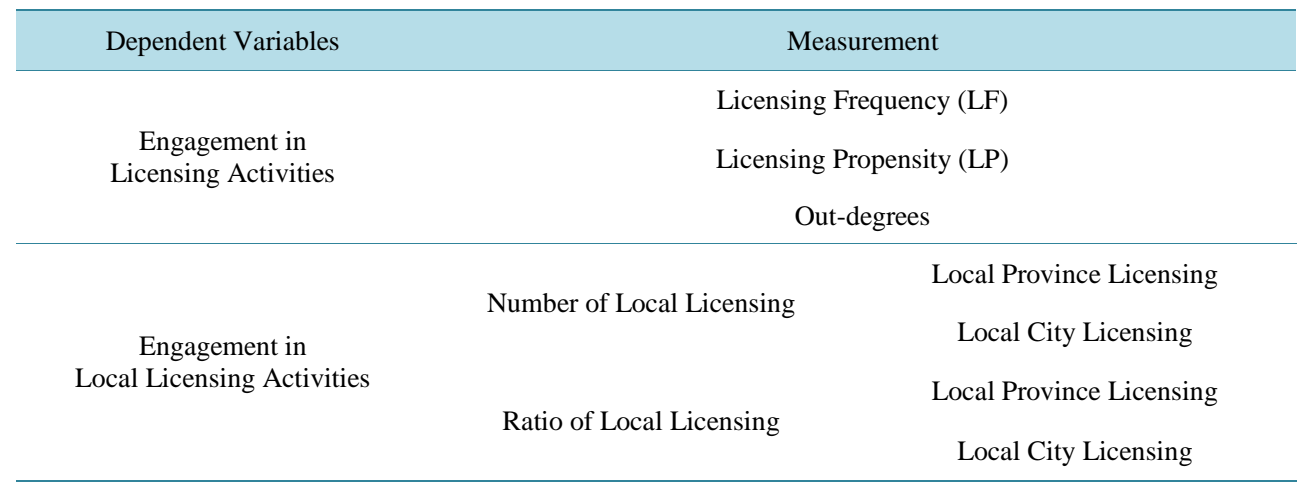

Table 4. The independent variables in ANOVA.

\begin{tabular}{|c|c|c|c|c|c|}
\hline Hypotheses & Independent Variables & Levels & Categories & Range & Sample Count \\
\hline \multirow{7}{*}{$\mathrm{H} 1$} & \multirow{7}{*}{$\begin{array}{l}\text { Patent } \\
\text { Stock }\end{array}$} & \multirow{7}{*}{7 Levels } & 1 Level & $1-50$ & 58 \\
\hline & & & 2 Level & $51-100$ & 42 \\
\hline & & & 3 Level & $101-200$ & 66 \\
\hline & & & 4 Level & $201-300$ & 44 \\
\hline & & & 5 Level & $301-500$ & 44 \\
\hline & & & 6 Level & $501-1000$ & 43 \\
\hline & & & 7 Level & 1001 - Highest & 50 \\
\hline \multirow{4}{*}{$\mathrm{H} 2$} & \multirow{4}{*}{$\begin{array}{c}\text { Local } \\
\text { Economic } \\
\text { Development } \\
\text { (City) }\end{array}$} & \multirow{4}{*}{4 Levels } & Low & $1-300 b$ & 89 \\
\hline & & & Mediate & $301-500 b$ & 81 \\
\hline & & & High & $501-1000 b$ & 98 \\
\hline & & & Higher & 1001 b - Highest & 79 \\
\hline \multirow{4}{*}{$\mathrm{H} 2$} & & \multirow{4}{*}{4 Levels } & Low & $0-1500 b$ & 91 \\
\hline & $\begin{array}{c}\text { Local } \\
\text { Economic }\end{array}$ & & Mediate & $1501 b-2300 b$ & 97 \\
\hline & $\begin{array}{l}\text { Development } \\
\text { (Province) }\end{array}$ & & High & 2301 b - 5000 b & 74 \\
\hline & & & Higher & 5000b - Highest & 85 \\
\hline \multirow{2}{*}{ H3 } & $\begin{array}{c}\text { Central } \\
\text { Government }\end{array}$ & \multirow{2}{*}{2 Levels } & 1 & Central & 69 \\
\hline & Support & & 0 & Local & 278 \\
\hline \multirow[b]{2}{*}{$\mathrm{H} 4$} & \multirow[b]{2}{*}{ TTOs } & \multirow[b]{2}{*}{2 Levels } & 1 & With TTOs & 121 \\
\hline & & & 0 & Without TTOs & 226 \\
\hline \multirow{2}{*}{ H5 } & \multirow{2}{*}{$\begin{array}{c}\text { Local } \\
\text { Administration }\end{array}$} & \multirow{2}{*}{2 Levels } & 1 & Local Admin & 278 \\
\hline & & & 0 & Central Admin & 69 \\
\hline
\end{tabular}

between groups. An eta squared value measures the strength of the association between the independent variable and the dependent variable. It is defined as "the proportion of total variation attributable to the factor, partialling out (excluding) other factors from the total nonerror variation” (J. Cohen, 1973). Its value represents the proportion of variance attributable to the factor and the associated error variation (Kachra \& White, 2008). In the following analyses, only those effects with significant $P$-values $\left(^{*}\right)$, which implied a significant difference between groups, would be analyzed in details. 
Table 5. The results of Levene Test on homogeneity.

\begin{tabular}{ccccccccc}
\hline P-Value & LF & LP & $\begin{array}{c}\text { Out } \\
\text { Degree }\end{array}$ & $\begin{array}{c}\text { Local Province } \\
\text { Licensing Number }\end{array}$ & $\begin{array}{c}\text { Local City } \\
\text { Licensing Number Licensing Ratio Licensing Ratio }\end{array}$ & $\begin{array}{c}\text { Local Province } \\
\text { (LF) }\end{array}$ \\
\hline Patent Stock & $0.0000^{*}$ & $0.0000^{*}$ & $0.0000^{*}$ & $0.0000^{*}$ & $0.0000^{*}$ & 0.4443 & $0.0000^{*}$ & 0.0016 \\
Province GDP & 0.3545 & 0.2025 & 0.574 & 0.026 & 0.1117 & $0.0000^{*}$ & 0.1629 & 0.4184 \\
City GDP & 0.0380 & 0.1886 & 0.0109 & 0.3641 & 0.1851 & 0.0205 & $0.0000^{*}$ & 0.1124 \\
$\begin{array}{c}\text { Central Government } \\
\text { Support }\end{array}$ & $0.0000^{*}$ & 0.0191 & $0.0000^{*}$ & $0.0000^{*}$ & $0.0000^{*}$ & 0.0013 & $0.0000^{*}$ & 0.6258 \\
TTOs & $0.0000^{*}$ & 0.2978 & $0.0000^{*}$ & $0.0001^{*}$ & $0.0000^{*}$ & 0.0099 & $0.0000^{*}$ & 0.0148 \\
Local Administration & $0.0000^{*}$ & 0.0191 & $0.0000^{*}$ & $0.0000^{*}$ & $0.0000^{*}$ & 0.0013 & $0.0000^{*}$ & 0.6258 \\
\hline
\end{tabular}

${ }^{*} P \leq 0.001$.

Table 6. Main results on ANOVA.

\begin{tabular}{|c|c|c|c|c|}
\hline Independent Variables & Dependent Variables & F-Value & $P$-Value & Eta squared \\
\hline Patent Stock & LOG (LF) & 94.4 & $0.0000\left({ }^{*}\right)$ & 0.6215 \\
\hline \multirow{4}{*}{ Province GDP } & $\mathrm{LF}$ & 1.341 & 0.261 & 0.0114 \\
\hline & LP & 2.026 & 0.11 & 0.0172 \\
\hline & Out Degree & 0.83 & 0.478 & 0.0071 \\
\hline & LOG (LF) & 4.11 & $0.0069\left(^{*}\right)$ & 0.0342 \\
\hline \multirow{4}{*}{ City GDP } & LF & 3.442 & 0.017 & 0.0288 \\
\hline & LP & 1.699 & 0.167 & 0.0144 \\
\hline & Out Degree & 4.331 & $0.0051\left(^{*}\right)$ & 0.0360 \\
\hline & LOG (LF) & 9.099 & $0.0000\left(^{*}\right)$ & 0.072 \\
\hline \multirow{2}{*}{ Central Government Support } & LP & 5.623 & 0.0183 & 0.0158 \\
\hline & LOG (LF) & 123.1 & $0.0000\left(^{*}\right)$ & 0.2602 \\
\hline \multirow{2}{*}{ TTOs } & LP & 0.807 & 0.37 & 0.0023 \\
\hline & LOG (LF) & 36.31 & $0.0000\left(^{*}\right)$ & 0.0940 \\
\hline Local Administration & Local Province Licensing Ratio & 11.09 & $0.0009\left({ }^{*}\right)$ & 0.0307 \\
\hline
\end{tabular}

${ }^{*} P \leq 0.01$.

\section{1) Results on Patent Stock Numbers (H1)}

The patent stock numbers had been classified into 7 levels based on their amount. A significant $P$ value $(P<$ 0.01) in Table 6 represents the differences in the logarithm of LF between 7 levels were significant. A large eta squared $(\eta 2=0.6215$ ) shows a large effective size of the independent variable on the dependent variable. The $P$ value only tells the existence of significant effects. Post hoc tests had been used to measure the detailed difference between each level. The TukeyHSD method had been used for post hoc tests in this study. The $P$ values in post hoc tests between each level could tell the differences and the results had been represented in Table 7 . The main content in Table 7 showed the mean licensing frequency of each level (transformed from the logarithm results). Numbers in the brackets were the logarithms result of these means. Based on the $P$ values in TukeyHSD method, the 7 levels could be assigned into 3 classes. Level 7 belonged to the first class, which had significant difference between other levels. Level 6 and Level 5 belonged to the second class, where there were no difference between level 6 and level 5 but significant differences of these 2 levels between the other levels. Level 4 , Level 3, Level 2 and Level 1 belonged to the third class for there was no difference in LOG(LF) numbers be- 
Table 7. Classes in patent stock numbers of licensing frequency.

\begin{tabular}{|c|c|c|c|c|}
\hline Levels & Range & First Class & Second Class & Third Class \\
\hline Level 7 & 1001 - Highest & $51.28(\log ($ lf $)=1.71)$ & & \\
\hline Level 6 & $501-1000$ & & $12.88(\log (\mathrm{lf})=1.11)$ & \\
\hline Level 5 & $301-500$ & & $8.91(\log (\mathrm{lf})=0.95)$ & \\
\hline Level 4 & $201-300$ & & & $4.37(\log (\mathrm{lf})=0.64)$ \\
\hline Level 3 & $101-200$ & & & $3.80(\log (\mathrm{lf})=0.58)$ \\
\hline Level 2 & $51-100$ & & & $2.34(\log ($ lf $)=0.37)$ \\
\hline Level 1 & $1-50$ & & & $1.55(\log (\mathrm{lf})=0.19)$ \\
\hline
\end{tabular}

tween the lower level and next higher levels. These results revealed the differences of licensing activities engagement of universities with various amount of patent stocks. Universities, which had patent stocks large than 1000, had much high average licensing frequency (51.28) than those with less. Universities with patent stocks ranging from 300 to 1000 had relative high average licensing frequency than those with patent stocks less than 300. These results are consistent with H1, which had predicted that universities with more patent stocks show more engagement on licensing activities. However, licensing frequency performance within each class does not show significant difference. This result implies that with few numbers of patent stocks (less than 300), universities' engagement in licensing activities are all relative inactive whether their patent stocks number are 1 or 300 .

\section{2) Results on Local Economic Development (H2)}

The Province GDP and City GDP had been used as independent variables to measure the local economic development. The Province GDP and City GDP had been classified into 4 levels based on their amount. The main results were shown on Table 8 and Table 9.

Results on the effects of province GDP contradicted with the statement in H2, which predicted a higher level of licensing frequency in universities in economically prosperous provinces. In the second column of Table 8, universities with mediate GPD level showed highest performance in LF while universities in high GDP level showed lowest performance in LF. $P$ values in Table 9 showed the significance of differences between each level. In province GDP, only the difference between high level and mediate level are effective. There is no significant difference in the logarithm of LF between other levels.

Results on the effects of city GDP were consistent with $\mathrm{H} 2$ and the mean values of out degrees (the number of licensees) and logarithm of LF showed an increasing pattern from low level to the highest level. In the out degree, significant differences had been shown between low level and higher level. In the mean of logarithm of LF, significant differences had been shown in 3 pairs: higher and low, high and low, higher and mediate.

\section{3) Results on Government Support (H3)}

The difference of mean logarithm of LF between universities with central government support and universities with local government support was significant based on the $P$ value in Table 6. In Table 10, the mean of LF with central government support was 25.7, much higher than the mean with local government support (4.17). With a relative high value of effect size $(\eta 2=0.2602)$, the results were consistent with the statement in $\mathrm{H} 3$, which predicted that universities, which gained central government support, show more engagement on licensing activities.

\section{4) Results on TTOs (H4)}

The difference of mean logarithm of LF between universities with official technology transfer offices (TTOs) and universities without it was significant based on the $P$ value in Table 6. In Table 10, the mean of LF with TTOs was 10.47, higher than the mean without TTOs (4.17). The results were consistent with the statement in H4, which predicted that universities, which had official TTO (Technology Transfer Office), show more engagement on licensing activities. However, the effect size in this relation was very low ( $\eta 2=0.0940)$, the impact of TTOs on universities licensing activities was limited.

\section{5) Results on Local Administrations (H5)}

The difference of mean local province licensing ratio between universities supervised by local government and universities supervised by central government was significant based on the $P$ value in Table 6. In Table 10, 
Table 8. Results of local economic development on licensing performance.

\begin{tabular}{cccc}
\hline & Province GDP & \multicolumn{2}{c}{ City GDP } \\
\cline { 2 - 4 } & Mean $(\log (\mathrm{lf}))$ & Mean $($ Out-Degree $)$ & Mean $(\log (\mathrm{lf}))$ \\
\hline Higher & $6.91(\log (\mathrm{lf})=0.84)$ & 19.38 & $9.55(\log (\mathrm{lf})=0.98)$ \\
High & $4.17(\log (\mathrm{lf})=0.62)$ & 15.70 & $7.41(\log (\mathrm{lf})=0.87)$ \\
Mediate & $7.94(\log (\mathrm{lf})=0.90)$ & 9.87 & $5.01(\log (\mathrm{lf})=0.70)$ \\
Low & $4.90(\log (\mathrm{lf})=0.69)$ & 6.30 & $3.55(\log (\mathrm{lf})=0.55)$ \\
\hline
\end{tabular}

Table 9. The difference significance between each levels ( $P$-values in TukeyHSD method).

\begin{tabular}{|c|c|c|c|c|}
\hline$P$-Values & Higher & High & Mediate & Low \\
\hline \multicolumn{5}{|l|}{ Higher } \\
\hline High & $0.0887,0.7892,0.5750$ & & & \\
\hline Mediate & $0.9113,0.1077,0.0165\left(^{*}\right)$ & $0.0120\left(^{*}\right), 0.4601,0.2487$ & & \\
\hline Low & $0.33977,0.0063\left(^{*}\right), 0.0000\left(^{*}\right)$ & $0.8649,0.0621,0.0011\left(^{*}\right)$ & $0.0756,0.8093,0.3307$ & \\
\hline
\end{tabular}

${ }^{*} P \leq 0.05$. Firs number in each cell showed the $P$ value in province GDP to $\log ($ lf). Second number in each cell showed the $P$ value in city GDP to out-degree. Third number in each cell showed the $P$ value in city GDP to $\log (\mathrm{lf})$.

Table 10. Results on government support, TTOs and local administration.

\begin{tabular}{|c|c|c|c|c|}
\hline & & Mean $(\lg (l f))$ & Mean (Local Province Licensing Ratio) & Eta Squared \\
\hline \multirow{2}{*}{$\begin{array}{l}\text { Central Government } \\
\text { Support }\end{array}$} & With & $25.70(\log (\mathrm{lf})=1.41)$ & & \multirow{2}{*}{0.2602} \\
\hline & Without & $4.17(\log (\mathrm{lf})=0.62)$ & & \\
\hline \multirow{2}{*}{ TTOs } & With & $10.47(\log (\mathrm{lf})=1.02)$ & & \multirow{2}{*}{0.0940} \\
\hline & Without & $4.26(\log (\mathrm{lf})=0.63)$ & & \\
\hline \multirow{2}{*}{ Local Administration } & With & & 0.64 & \multirow{2}{*}{0.0307} \\
\hline & Without & & 0.48 & \\
\hline
\end{tabular}

the mean of local province licensing ratio in universities supervised by local government was $64 \%$, higher than the mean in universities supervised by central government (48\%). The results were consistent with the statement in $\mathrm{H} 5$, which predicted that universities, which were supervised by local government, show more engagement on local licensing activities. However, the effect size in this relation was very low $(\eta 2=0.0307)$, the impact of local administration on universities licensing directions was so limited.

\section{Discussions and Conclusions}

This paper had analyzed the patent licensing performance of the whole Chinese universities. Previous works on Chinese university patenting never get the specific data about licensing activities. Although there had been some statement about the low level of licensing performance of Chinese universities, the exact level of licensing performance had not been measured in a comprehensive way. In this paper, the licensing documents of all Chinese universities had been collected and analyzed. The exact performance of Chinese universities patent licensing had been revealed, that is only 6\% of patents stocks (16.03 patents per university) had been transferred through licensing till the end of 2012. This low level of licensing frequency and licensing proportion was shocking to some extent. Although the Chinese universities had engaged actively in patent application activities, a large number of these academic innovation outputs had not been transferred into industries. Inventions that could not be commercialized were a great waste of public resources and funds. The mere $7 \%$ of licensing proportion should be a warning to the Chinese university-industry public policy.

Another finding in this paper is that Chinese universities tend to commercialize academic inventions with companies in the local area, which conform to the studies launched in the US (Agrawal, 2000) which had revealed the importance of interactions in technology transfer. The distance between licensors and licensees showed impact on the licensing frequency. However, the effect was only obvious between very near distance and 
very far away distance. When the distances were within a middle level range (in this study, it's $400 \mathrm{~km}$ to 2200 $\mathrm{km}$ ), there is no significant difference within. These result could brought some insights into the policy making process in Chinese government. More effort should be made to facilitate the technology transfer process from universities to nearby industries. Companies that located near high-tech universities could have more access to the academic inventions and have more interactions with the research team, which could generate more chance of technology transfer. The localization effect of universities patent licensing would not occur when the distance between licensors and licensees were increased out off a certain boundary (in this study, it's $400 \mathrm{~km}$ ).

To have a more clear view on the patterns of university licensing activities, this paper had brought up 5 hypotheses about the patterns of licensing performance and tested these hypotheses using ANOVA method. All 5 hypotheses had been confirmed within the dataset. Universities with large amount of patent stocks, or located in economically prosperous districts, or with the support of central government, or have official TTO in organization structure, had more patents licensed out. However, the effect of local economic performance only significant on the local city level, not on the local province level. These findings had confirmed the effect of these factors on university licensing activities. In the concern of public policies on university-industry interactions, efforts had to be made to reduce the blocks in patent licensing in universities with high levels of patent stock numbers for these universities had more intentions in technology transferring. The economic environment on the universities local city could affect patent licensing frequency and efforts should be made to promote the economic performance of local cities and introduce more private enterprises into the environment. Universities that were supported and supervised by central government department tend to reveal high performance in patent licensing. This had brought up the importance of support from central government in the Chinese context. The results on TTOs in Chinese universities had confirmed the effect of this official organizational structure in the Chinese environment. Universities should put more investment into this office and those universities which had no such office should establish TTOs in their organizational structure in order to promote the academic innovation transferring efficiency. However, considering the relative low level of eta squared results, which represented effective size, the effects of local city economic environment and the effect of TTOs in organizational structures are limited. Patent stocks and central government support had large effect size on the variance of licensing performance and should be favored in the public policy. In the test of patterns in local licensing activities (patents been licensed to companies in local area), universities that were supervised by local government tend to transfer more patents to the local province industries. This result had revealed the impact of local government on the local technology transferring process. Since local government had invested more resources and funds in universities that were under local supervisions, the payback from this investment is significant.

The limitation of this paper is pretty obvious for it had only dug into one of the knowledge transferring process from university to industry. Patent licensing is a crucial channel in this process. However, the knowledge transferring performance of other channels, such as contract research, personnel exchange, consulting and so on, had not been studied in a comprehensive way. Performance of other channels should be studied in the future work. And also, this paper had only tested 5 hypotheses on the performance of university licensing, which was not enough, considering the complexity in technology transferring process.

In recent decades, Chinese university patent application numbers had increased dramatically (Luan et al., 2010). However, their performance on patent licensing is rather disappointing based on the results in this paper. Efforts had to be made to facilitate patent licensing process and studies concentrating on this process would hold their value in the future.

\section{Acknowledgements}

This work was supported by the National Natural Science Foundation of China under Grant Nos. 71202054, the Soft Science Research Project of Anhui Province of China under Grant Nos. 1402052002, and "the Fundamental Research Funds for the Central Universities”.

\section{References}

Abramo, G., D’Angelo, C. A., \& Solazzi, M. (2012). A bibliometric Tool to Assess the Regional Dimension of University-Industry Research Collaborations. Scientometrics, 91, 955-975. http://dx.doi.org/10.1007/s11192-011-0577-5

Agrawal, A. (2000). Importing Scientific Inventions: Direct Interaction, Geography, and Economic Performance. University of British Columbia Mimeo, Doctoral Thesis, University of British Columbia. 
Agrawal, A. (2001). University-to-Industry Knowledge Transfer: Literature Review and Unanswered Questions. International Journal of Management Reviews, 3, 285-302. http://dx.doi.org/10.1111/1468-2370.00069

Baldini, N. (2006). University Patenting and Licensing Activity: A Review of the Literature. Research Evaluation, 15, 197207. http://dx.doi.org/10.3152/147154406781775878

Bozeman, B. (2000). Technology Transfer and Public Policy: A Review of Research and Theory. Research Policy, 29, 627-655. http://dx.doi.org/10.1016/S0048-7333(99)00093-1

Cohen, J. (1973). Eta-Squared and Partial Eta-Squared in Fixed Factor ANOVA Designs. Educational and Psychological Measurement. http://dx.doi.org/10.1177/001316447303300111

Cohen, W. M., Nelson, R. R., \& Walsh, J. P. (2002). Links and Impacts: The Influence of Public Research on Industrial R\&D. Management Science, 48, 1-23. http://dx.doi.org/10.1287/mnsc.48.1.1.14273

Colyvas, J., Crow, M., Gelijns, A., Mazzoleni, R., Nelson, R. R., Rosenberg, N., \& Sampat, B. N. (2002). HOW do University Inventions Get into Practice? Management Science, 48, 61-72. http://dx.doi.org/10.1287/mnsc.48.1.61.14272

Etzkowitz, H., \& Leydesdorff, L. (2000). The Dynamics of Innovation: From National Systems and “Mode 2” to a Triple Helix of University-Industry-Government Relations. Research Policy, 29, 109-123.

http://dx.doi.org/10.1016/S0048-7333(99)00055-4

Gao, X., Guo, X., \& Guan, J. C. (2014). An Analysis of the Patenting Activities and Collaboration among Industry-University-Research Institutes in the Chinese ICT Sector. Scientometrics, 98, 247-263.

http://dx.doi.org/10.1007/s11192-013-1048-y

Hong, W. (2008). Decline of the Center: The Decentralizing Process of Knowledge Transfer of Chinese Universities from 1985 to 2004. Research Policy, 37, 580-595. http://dx.doi.org/10.1016/j.respol.2007.12.008

Kachra, A., \& White, R. E. (2008). Know-How Transfer: The Role of Social, Economic/Competitive, and Firm Boundary Factors. Strategic Management Journal, 29, 425-445. http://dx.doi.org/10.1002/smj.668

Lee, Y. G. (2008). Patent Licensability and Life: A Study of US Patents Registered by South Korean Public Research Institutes. Scientometrics, 75, 463-471. http://dx.doi.org/10.1007/s11192-007-1879-5

Lei, X. P., Zhao, Z. Y., Zhang, X., Chen, D. Z., Huang, M. H., \& Zhao, Y. H. (2012). The Inventive Activities and Collaboration Pattern of University-Industry-Government in China Based on Patent Analysis. Scientometrics, 90, $231-251$. http://dx.doi.org/10.1007/s11192-011-0510-y

Li-Ying, J., Wang, Y. D., Salomo, S., \& Vanhaverbeke, W. (2013). Have Chinese Firms Learned from Their Prior Technology In-Licensing? An Analysis Based on Patent Citations. Scientometrics, 95, 183-195. http://dx.doi.org/10.1007/s11192-012-0802-X

Luan, C. J., Zhou, C. Y., \& Liu, A. Y. (2010). Patent Strategy in Chinese Universities: A Comparative Perspective. Scientometrics, 84, 53-63. http://dx.doi.org/10.1007/s11192-010-0194-8

Macho-Stadler, I., Perez-Castrillo, D., \& Veugelers, R. (2007). Licensing of University Inventions: The Role of a Technology Transfer Office. International Journal of Industrial Organization, 25, 483-510. http://dx.doi.org/10.1016/j.ijindorg.2006.06.001

Mowery, D. C., Nelson, R. R., Sampat, B. N., \& Ziedonis, A. A. (2001). The Growth of Patenting and Licensing by US Universities: An Assessment of the Effects of the Bayh-Dole Act of 1980. Research Policy, 30, 99-119. http://dx.doi.org/10.1016/S0048-7333(99)00100-6

Mowery, D. C., \& Ziedonis, A. A. (2002). Academic Patent Quality and Quantity before and after the Bayh-Dole Act in the United States. Research Policy, 31, 399-418. http://dx.doi.org/10.1016/S0048-7333(01)00116-0

Shane, S. (2002). Selling University Technology: Patterns from MIT. Management Science, 48, 122-137. http://dx.doi.org/10.1287/mnsc.48.1.122.14281

Shane, S., \& Somaya, D. (2007). The Effects of Patent Litigation on University Licensing Efforts. Journal of Economic Behavior \& Organization, 63, 739-755. http://dx.doi.org/10.1016/j.jebo.2006.05.012

Thursby, J. G., \& Kemp, S. (2002). Growth and Productive Efficiency of University Intellectual Property Licensing. Research Policy, 31, 109-124. http://dx.doi.org/10.1016/S0048-7333(00)00160-8

Thursby, J. G., \& Thursby, M. C. (2002). Who Is Selling the Ivory Tower? Sources of Growth in University Licensing. Management Science, 48, 90-104. http://dx.doi.org/10.1287/mnsc.48.1.90.14271

Wang, Y. D., Huang, J. S., Chen, Y. T., Pan, X. F., \& Chen, J. (2013). Have Chinese Universities Embraced Their Third Mission? New Insight from a Business Perspective. Scientometrics, 97, 207-222. http://dx.doi.org/10.1007/s11192-013-1055-z

Wu, W., \& Zhou, Y. (2012). The Third Mission Stalled? Universities in China's Technological Progress. The Journal of Technology Transfer, 37, 812-827. http://dx.doi.org/10.1007/s10961-011-9233-8 
Scientific Research Publishing (SCIRP) is one of the largest Open Access journal publishers. It is currently publishing more than 200 open access, online, peer-reviewed journals covering a wide range of academic disciplines. SCIRP serves the worldwide academic communities and contributes to the progress and application of science with its publication.

Other selected journals from SCIRP are listed as below. Submit your manuscript to us via either submit@scirp.org or Online Submission Portal.
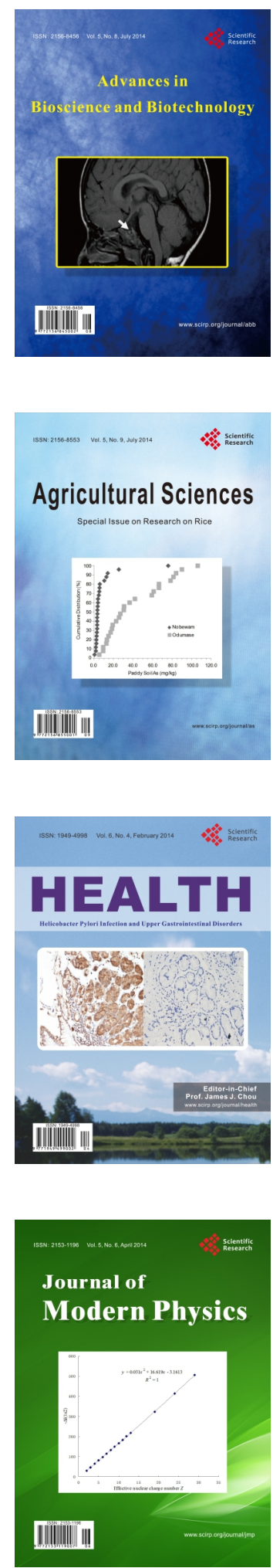
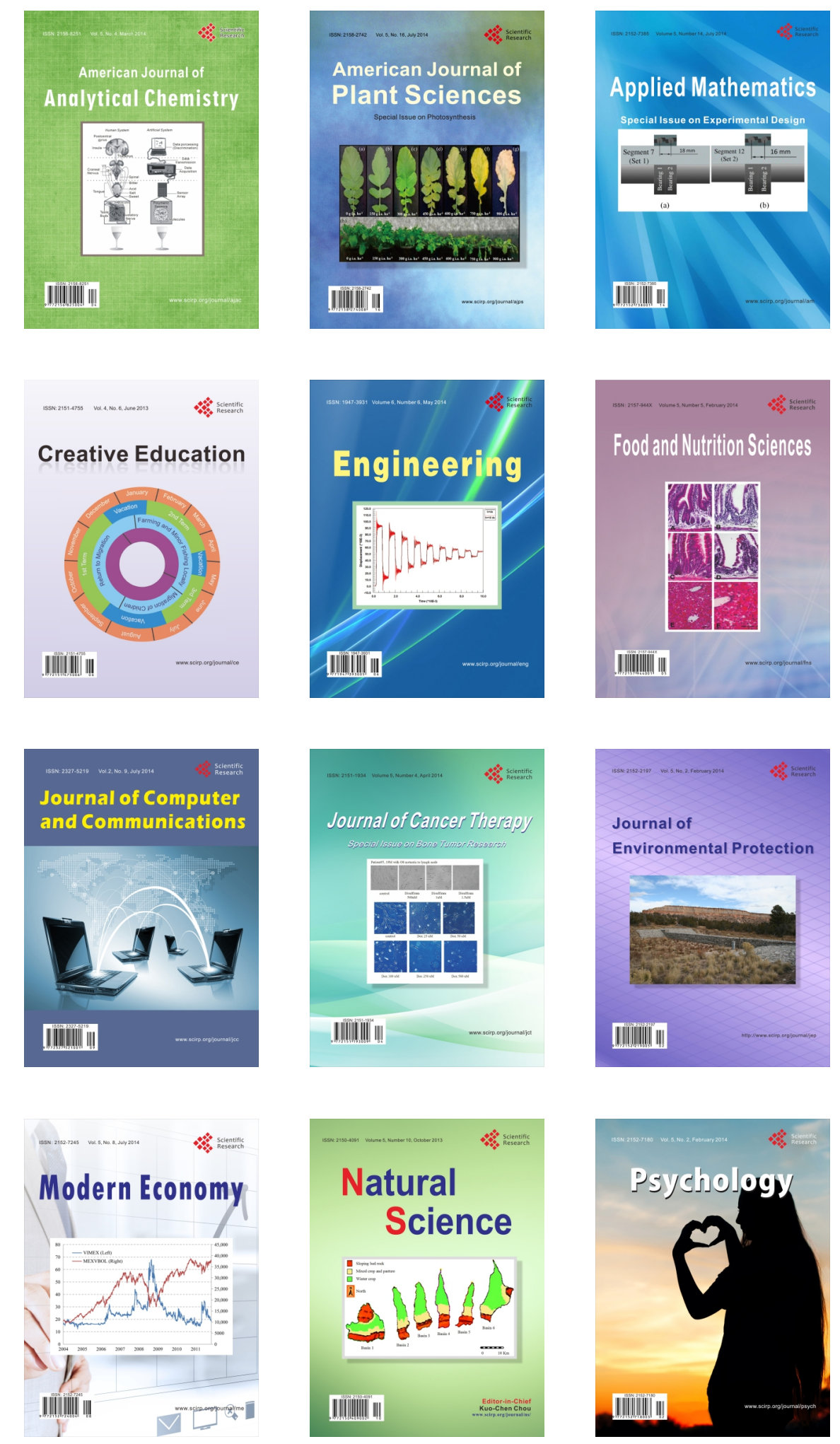